\title{
Prenatal Diagnosis of a Rare Type of Conjoined Twin, Cephalothoracoomphalopagus: A Case Report
}

\section{Yapışık İkizin Nadir Bir Türü Olan Sefalotorakoomfaloselin Prenatal Tanısı: Olgu Sunumu}

\section{(D) Yasin Ceylan¹, (D) Bertan Akar², (D) İlteriş Yaman¹, (D Selim Akkaya}

${ }^{1}$ University of Health Sciences Turkey, İstanbul Bağcılar Training and Research Hospital, Clinic of Obstetrics and Gynecology, İstanbul, Turkey 2İstinye University Faculty of Medicine; Private Kocaeli Hospital, Clinic of Obstetrics and Gynecology, İstanbul, Kocaeli, Turkey

\section{Abstract}

Conjoined twins are a rare outcome of a monoamniotic and monochorionic gestation. We present a case of cephalothoracoomphalopagus conjoined twin diagnosed by prenatal ultrasonographic examination. A 26-yearold gravida 2, para 1 woman was referred to our perinatology unit for evaluation because of suspected conjoined twins at 24 weeks of gestation. Her medical history was unremarkable. There was no family history of genetic abnormalities. The diagnosis of conjoined twins was confirmed by prenatal ultrasonographic examination. Conjoined twins occur when two identical individuals are joined by part of their anatomy and share their vital one or more organs. The incidence of conjoined twins ranges from 1:50,000 to 1:250,000 live births. We present a case of male cephalothoracoomphalopagus conjoined twin, which is extremely rare type of conjoined twins. A prenatal diagnosis of shared organs dictates pregnacy termination or possible surgical separation strategies.

Keywords: Conjoined, prenatal, prenatal diagnosis, twins, ultrasonography

\section{Öz}

Nadir görülen yapışık ikizler monoamniyotik ve monokoryonik gebelik sonucu oluşur. Biz prenetal ultrasonografik muayene ile tanı konulan sefalotorakoomfoloselli yapışık ikiz olgusunu sunuyoruz. Yirmi altı yaşında, gravida 2, parite 1 kadın hasta, 24 haftalık şüpheli yapışı ikiz tanısıyla bizim perinatoloji ünitesine sevk edilmişti. Genetik anamoli açısından aile öyküsü yoktu. Yapışık ikiz tanısı prenatal ultrasonografik muayene ile onaylandı. Yapışık ikizler aynı iki bireyin anatomik bölümlerinin birleşmesi ile ve bir veya daha çok vital organlarının paylaşııması ile oluşur. Yapışık ikiz insidansı her canlı doğumda 1:50.000'den 1:250.000'e kadar değişir. Biz yapışık ikizlerin nadir bir türü olan erkek sefalotorakoomfoloselli yapışık ikiz olgusunu sunduk. Paylaşılan organların prenatal tanısı gebelik terminasyonunun kabul ettirilmesi veya cerrahi seperasyon yöntemleri ile konulur.

Anahtar kelimeler: Bitişik, ikizler, prenatal, prenatal tanı, ultrasonografi

\section{Introduction}

Conjoined twin is a very rare condition and its incidence varies from $1 / 50,000$ to $1 / 250,000$ per live birth. It is also possible to be seen in $1 \%$ of monozygotic twins (1). Although antenatal diagnosis is very difficult, it is very important. In this case report, we presented a case of conjoined twins with a rare diagnosis of cephalothoracoomphalopagus.

\section{Case Report}

A 26-year-old female patient with gravida 2 and parity 1 was referred to the perinatology unit of our clinic with

Address for Correspondence: Yasin Ceylan, University of Health Sciences Turkey, İstanbul Bağclar Training and Research Hospital, Clinic of 
the suspicion of twin anomaly at 24 weeks. There was no feature in the patient's history. There was no family history for genetic anomaly. In prenatal ultrasonographic examination, monochorionic monoamniotic twin pregnancy with 4 upper extremities, 4 lower extremities, 2 hearts, 2 kidneys, 2 lungs, single cerebrum, single head and single umblical cord was observed. Conjoined twins were diagnosed ultrasonographically. Termination was offered to the patient, but she refused. When the patient was 25 weeks old, she applied to our clinic with the complaint of water leakage. Active water discharge was observed in her vaginal examination. Spontaneous vaginal delivery occurred when the patient was 25 weeks and 1 day old. Conjoined twin ex fetuses were observed in male genders with attached head and thorax regions. His macroscopic examination supported the prenatal ultrasonographic data (Figure 1). Pathological examination result was reported as conjoined twins in male gender with anal atresia with single cerebrum, mouth, pituitary, umbilical cord, esophagus, larynx, stomach, intestine and pancreas, 3 adrenal glands, 2 kidneys, 2 hearts, 2 lungs, adhered to each other from the head and thorax parts.

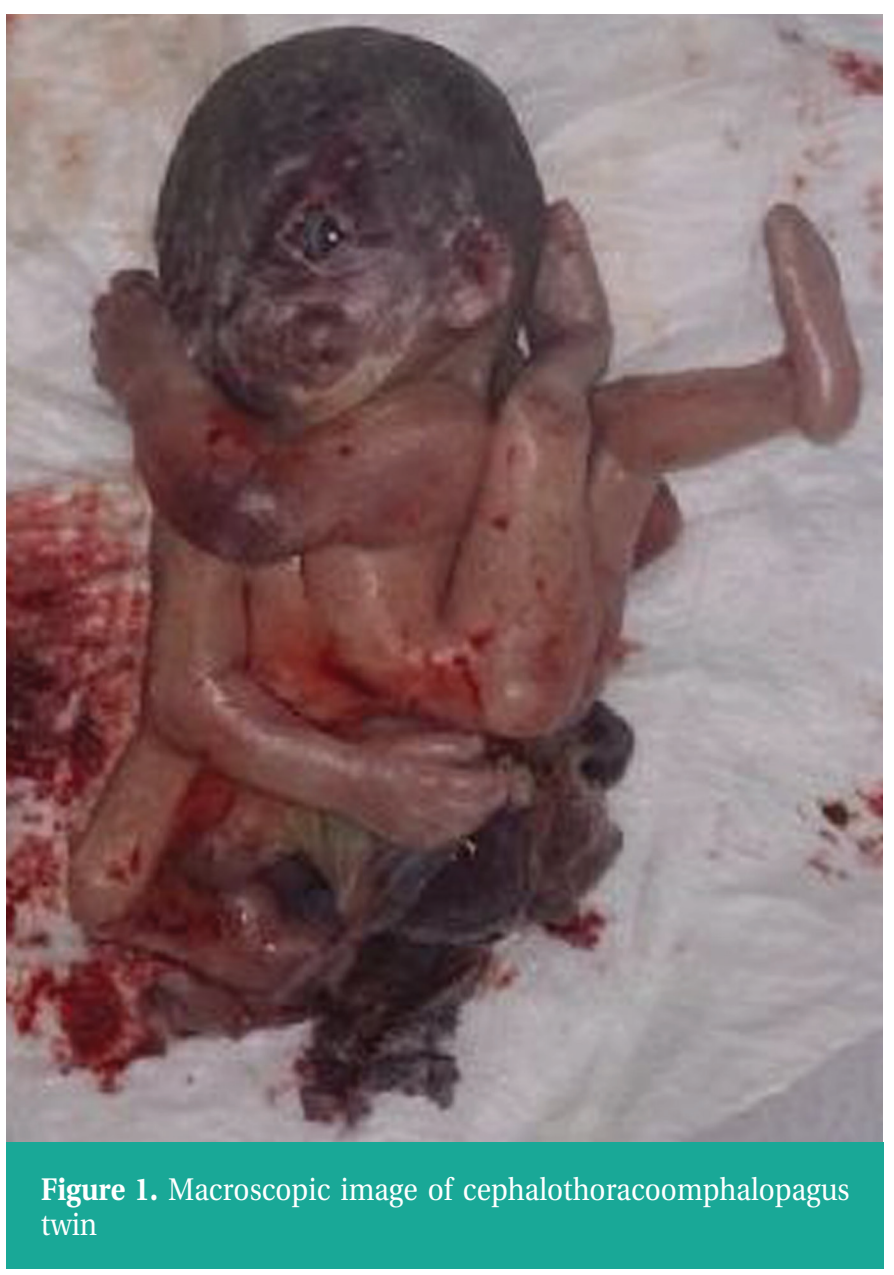

\section{Discussion}

Conjoined twin is a very rare form of monozygotic twins. This is seen in monochorionic monoamniotic pregnancies. It occurs as a result of incomplete separation of a single fertilized ovum between the $15^{\text {th }}$ and $17^{\text {th }}$ gestational days $(1,2)$. It is generally seen in female fetuses. Births of conjoined twins are very traumatic; these fetuses are usually premature. However, $60 \%$ of them are born alive and die in a very short time after birth (2). It is named according to the conjoined body areas. Cephalothoracoomphalopagus is the rarest type (3). Although prenatal diagnosis is very difficult, the possibility of conjoined twins should be considered in twin fetuses that cannot be well visualized in a single gestational sac in ultrasonographic examination (4). In such a situation, the diagnosis should be supported by fetal magnetic resonance imaging (MRI) (Figure 2). Diagnosis by ultrasonography and MRI in the early gestational week is important in making early termination decision with the approval of the family.

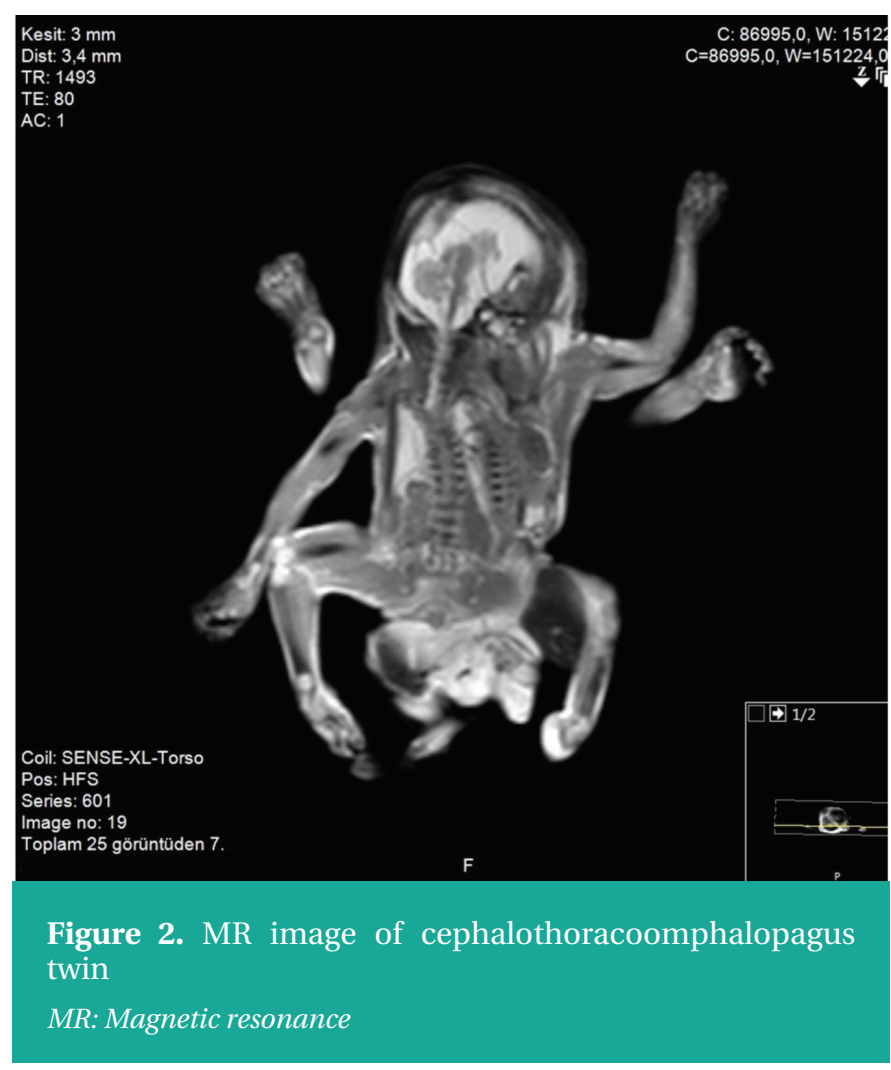




\section{Ethic}

Informed Consent: Consent of patient was taken.

Peer-review: Externally peer-reviewed.

\section{Authorship Contributions}

Follow-up of the Case: Y.C., İ.Y., S.A., Literature Review: B.A., S.A., Y.C., Writing: Y.C., İ.Y., B.A., Manuscript Review and Revisation: B.A., S.A., İ.Y.

Conflict of Interest: The authors declare that there is no conflict of interest with regard to this manuscript.

Financial Disclosure: No financial support was received from a person or a company for writing this case report.

\section{References}

1. Spitz L. Conjoined twins. Prenat Diagn 2005;25(9):814-819.

2. Sherer DM, Dalloul M, Kheyman M, Zigalo A, Nader I, Sokolovski $M$, et al. Transvaginal color Doppler imaging diagnosis of thoracopagus conjoined twins at 7 weeks' gestation. J Ultrasound Med 2006;25(11):1485-1487.

3. Koreti S, Prasad N, Patell GS. Cephalothoracoomphalopagus: a rare type of conjoined twin. J Clin Neonatol 2014;3(1):47-48.

4. Sharma UK, Dangol A, Chawla CD, Shrestha D. Antenatal detection of conjoined twin. JNMA J Nepal Med Assoc 2007;46(167):133-135. 